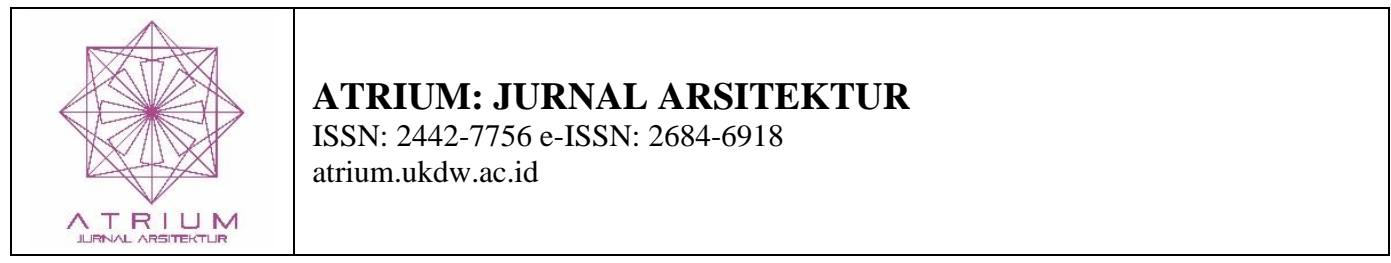

\title{
Pemanfaatan Google-Street-View untuk Observasi Kota di Tengah Pandemi Covid-19
}

| Diterima pada 22 Maret 2021 | Disetujui pada 18 Mei 2021 | Tersedia online 25 Mei 2021 | | DOI: https://doi.org/10.21460/atrium.v7i1.111 |

\author{
Setyo Nugroho ${ }^{1}$, Fardilla Rizqiyah ${ }^{2}$, Kirami Bararatin ${ }^{3}$, Angger Sukma \\ Mahendra $^{4}$, Rabbani Kharismawan ${ }^{5}$, Bambang Soemardiono ${ }^{6}$ \\ 1-6. Departemen Arsitektur, Fakultas Teknik Sipil Perencanaan dan Kebumian, \\ Institut Teknologi Sepuluh Nopember, \\ Kampus ITS Sukolilo, Surabaya \\ Email: setyo@its.ac.id
}

\begin{abstract}
Abstrak
Pengumpulan data untuk bidang arsitektur dan perancangan kota dilakukan dengan cara melakukan survey lapangan. Akan tetapi, di tengah kondisi pandemi covid-19 hal ini sukar untuk dilakukan karena adanya pembatasan aktivitas fisik di luar ruangan. Survey lapangan di dalam situasi pandemi dapat dilakukan melalui pemanfaatan Google-Street-View (GSV). Namun, belum ada artikel ilmiah yang menjelaskan secara sistematis topik apa saja yang dapat dibahas dalam bidang arsitektur dan perancangan kota menggunakan data GSV. Tujuan dari artikel ini adalah mengulas penerapan teknik observasi untuk pengumpulan data arsitektur dan perancangan kota dengan menggunakan GSV. Metode penelitian yang digunakan adalah tinjauan pustaka dari artikel-artikel terkait, dan studi kasus dari kota-kota di Indonesia maupun di luar negeri dengan metode naratif. Hasil pembahasan menyebutkan setidaknya ada 3 topik bahasan yang dapat menggunakan data GSV antara lain: evaluasi lanskap tepian jalan; pembacaan karakter kawasan; dan pelestarian arsitektur kota. Walaupun penerapan teknik observasi ini memiliki sejumlah kekurangan, namun teknik ini dapat memberikan fleksibilitas pada pengguna khususnya dosen, peneliti, dan mahasiswa untuk melengkapi pengumpulan data.
\end{abstract}

Kata kunci: arsitektur, kota, Google-Street-View, Covid-19

\section{Abstract}

Title: Making Use of Google-Street-View for Urban Observation During Covid-19 Pandemic

Data collection in the field of architecture and urban design has been conducted mostly onsite through field survey. Yet, covid-19 pandemic made this activity impossible due to the avoiding physical activities in public area. Field survey in the covid-19 pandemic can be conducted through the make use of GoogleStreet-View (GSV). However, previous articles did not explain sisytematically the topic in the scope of architecture and urban design which were possible to discuss by using GSV. The article aims to review the implementation of observation technique using GSV to support data collection in the field of architecture and urban design. Research method employs the literature review, and case studies from Indonesian cities and abroad by narrative method. The result showed that 3 topics of discussions were possible to use the GSV as a tool: streetscape evaluation; reading visual characteristics of the city and town; and architectural conservation. Even though some weaknesses were noticed, this technique of data collection give a flexibility for the user especially the lecturers, researchers, as well as students to complete their data collection.

Keywords: architecture, city, Google-Street-View, Covid-19 


\section{Pendahuluan}

Arsitektur dengan konsentrasi bidang perancangan kota mencoba melihat bangunan tidak hanya sebagai bangunan tunggal namun juga bagian dari konteks lingkungannya secara keseluruhan. Ruang-ruang antar bangunan membentuk ruang publik yang digunakan masyarakat untuk kegiatan sehari-hari. Di dalam ruang publik ini, kita dapat mengamati perilaku masyarakat terhadap ruang fisik kota. Pengamatan perilaku dapat dilakukan melalui observasi lapangan, wawancara, maupun Focus Group Discussion (FGD), mengingat bahwa FGD merupakan alat yang efektif untuk mengidentikasi bahan diskusi yang ada pada masyarakat (Soemardiono et al, 2019).

Dengan melakukan pengamatan atau observasi, kita dapat mengetahui bagaimana ruang digunakan (how), digunakan oleh siapa (by whom), dan fasilitas apa yang disediakan (what) (Lipovská \& Štěpánková, 2013). Observasi secara langsung di lokasi juga dapat membantu mengklarifikasi mengapa hanya ruang-ruang tertentu yang digunakan oleh masyarakat dan lainnya tidak (Gehl and Svarre, 2013). Ruang-ruang yang digunakan dan yang tidak digunakan ini tentunya dipengaruhi oleh banyak faktor yang meliputi faktor fisik dan non-fisik.

Sebuah contoh observasi aktivitas masyarakat di alun-alun kota sebagai ruang publik: (a) pengguna memiliki rentang usia yang bervariasi namun didominasi oleh usia 20-30 tahun; (b) fasilitas yang disediakan adalah kursi taman, tiang lampu, bak sampah, dan jalan setapak; (c) bagaimana pengguna memanfaatkan ruang dan respon terhadap ruang fisik secara detail tiap kelompok. Observasi sangat memungkinkan untuk mengetahui sebuah proses perilaku manusia dalam memanfaatkan ruang publik. Gehl menjelaskan dalam sebuah observasi sebuah bangku: bagaimana mereka duduk, saat bangku kosong mereka akan memilih duduk di sisi mana (tengah atau pinggir).

Observasi juga dapat diterapkan untuk melihat konsep complete street, yaitu sebuah kebijakan dan implementasi penataan jalan yang aman dan nyaman untuk seluruh pengguna (https://modelur.com/complete-streetsin-vancouver/, diakses 18 Maret 2021). Dalam pendekatan ini, jalur pejalan kaki, traffic calming, penghijauan, jalur sepeda dan tempat parkirnya menjadi perhatian yang besar. Tujuan dari complete street adalah meningkatkan kegiatan fisik masyarakat (physical activites) melalui berjalan kaki dan bersepeda. Tentunya pendekatan ini harus dibarengi dengan perencanaan transportasi yang komprehensif.

Pada bulan Maret 2020, Indonesia mengumumkan kasus pertama virus covid-19. Hingga 5 April 2021, telah tercatat 1.542.516 kasus dengan jumlah kasus aktif 114.475 (https://www.worldometers.info/coron avirus/country/indonesia/, diakses 7 April 2021). Meningkatnya penyebaran virus covid-19 di Indonesia menyebabkan banyak perubahan dalam segala bidang. Menanggapi kondisi ini, pemerintah telah menetapkan covid-19 sebagai bencana nasional non-alam melalui Keputusan Presiden Nomor 12 Tahun 2020 pada 13 April 2020. Di masa pandemi covid-19, ada batasan melakukan aktivitas di luar rumah dan himbauan berupa physical distancing untuk memutus mata rantai penyebaran virus covid-19. Skema working from 
home (WFH) mulai diterapkan dan menjadi bagian dari tatanan baru kegiatan keseharian (Mungkasa, 2020). Kondisi di tengah pandemi ini menyebabkan observasi secara langsung di lapangan menemui kendala. Pengamatan hanya bisa dilakukan secara jarak jauh menggunakan data terbuka yang tersedia di internet. Situasi seperti sekarang ini menjadi sebuah tantangan tersendiri khususnya bagi peneliti, dosen, dan mahasiswa di bidang arsitektur dan perancangan kota, karena data yang digunakan pada umumnya adalah data primer (observasi dan wawancara). Dengan kata lain, ada urgensi bahwa teknik pengumpulan data harus dilakukan dengan cara lain.

$\begin{array}{lrr}\text { Menurut } & \text { APJII } & \text { (Asosiasi } \\ \text { Penyelenggara } & \text { Jasa } & \text { Internet }\end{array}$ Indonesia), pada kuartal kedua tahun 2020, penetrasi internet atau persentase pengguna internet terhadap populasi di wilayah Indonesia adalah sebesar $73,7 \%$ naik dari $64,8 \%$ di tahun 2018 . Dibandingkan dengan tahun sebelumnya, pengguna internet mengalami peningkatan $8,9 \%$ dalam medio tahun 2020 (APJII, 2020). Jumlah penetrasi ini diperkuat dengan adanya kebijakan work from home dan school from home untuk mengurangi penyebaran virus covid-19 melalui kontak fisik.

Dalam bidang arsitektur dan perancangan kota, observasi melalui penggunaan internet dapat dilakukan melalui Google-Street-View (GSV). GSV merupakan data terbuka yang tidak asing bagi masyarakat luas. Teknologi ini dapat dimanfaatkan sebagai alat untuk melakukan observasi khususnya pada ruang-ruang kota. Sejauh ini, GSV digunakan untuk mengklarifikasi kondisi suatu tempat sebelum melakukan kunjungan secara langsung maupun mengamati suasana pemandangan kota yang ingin dikunjungi suatu hari. Namun sebenarnya, pengamatan dapat dilakukan lebih dari hal yang disebutkan di atas khususnya dalam bidang arsitektur dan kota. GSV merupakan bagian dari Google yang menyajikan pemandangan panorama $360^{\circ}$ secara sikuensial dari banyak negara lintas benua (Anguelov et al, 2010). Melalui fitur ini, setiap orang dapat menjelajahi dunia dari rumah sekalipun. Data yang berasal dari Google sendiri sebagian besar dilakukan dengan menggunakan mobil, namun ada juga yang menggunakan sepeda, boat, bahkan juga dengan berjalan kaki. Alat yang digunakan di punggung ini bertujuan untuk merekam jalan-jalan sempit yang tidak mungkin bisa dilalui oleh mobil (https://www.google.com/earth/educati on/tools/street-view/, diakses 19 Maret 2021).

Data yang direkam di dalam GSV mencakup negara-negara di seluruh penjuru dunia. Menurut data dari Google, ada setidaknya tiga kelompok wilayah yang direkam: pertama, kelompok negara yang terekam sebagian wilayahnya secara lengkap, seperti Thailand, Taiwan, Jepang, Australia, dsb. Kedua, kelompok negara yang terekam sebagian besar seperti Indonesia. Ketiga adalah kelompok negara yang hanya terekam Kawasan bisnis dan pariwisata saja seperti Tiongkok, Mesir, Papua Nugini, dsb. Sedangkan terakhir adalah kelompok negara yang hanya terekam pada titik bisnis swasta seperti Myanmar dan Sebagian Vietnam (https://en.wikipedia.org/wiki/Coverag e of Google_Street View, diakses 18 Maret 2021). 
Penelitian sebelumnya telah mengaplikasikan penggunaan data visual dari GSV khususnya dalam topik computer vision dan transportasi (Gebru et al, 2017 \& Sainju et al, 2020), kriminalitas (Vandeviver, 2014), dan studi kesehatan (Rzotkiewicz et al, 2018). Namun, sejauh ini belum terdapat ulasan yang mencoba merangkum pemanfaatan GSV untuk observasi kota. Ulasan ini akan membantu pengguna khususnya dosen, peneliti dan mahasiswa dalam melakukan pengumpulan data.

Berdasarkan pernyataan di atas, maka dapat dirumuskan permasalahan yang diangkat pada artikel ini, topik apa saja yang dapat diulas dengan menggunakan data GSV dalam lingkup arsitektur dan perancangan kota? Mengingat bahwa selama kondisi pandemi covid-19, kegiatan di luar ruangan termasuk observasi lapangan secara langsung sebaiknya dibatasi. Penulisan artikel ini bertujuan untuk memberikan ulasan secara singkat mengenai topik yang dapat diulas dengan menggunakan data GSV dalam lingkup arsitektur dan kota.

\section{Metode Penelitian}

Artikel ini menggunakan metode penelitian kepustakaan, yakni dengan cara memanfaatkan sumber pustaka untuk mendapatkan data penelitian (Zed, 2014). Menurut Zed (2014), ada empat ciri utama dalam melakukan studi kepustakaan:

- Berhadapan langsung dengan teks dan bukan data lapangan.

- Data yang siap pakai, sudah tersedia tanppa harus pergi ke lokasi tertentu.

- Sumber data bersifat sekunder.

- Kondisi data tidak dibatasi ruang dan waktu.
Data kepustakaan yang digunakan dalam artikel ini berasal dari: buku referensi, artikel ilmiah yang telah dipublikasikan, laporan akhir survey berkaitan dengan data statistik, dan sumber internet. Sumber internet yang digunakan antara lain berkaitan dengan data GSV.

Tahapan penelitian dalam artikel ini adalah sebagai berikut:

- Mengumpulkan artikel dan buku yang mengulas topik mengenai observasi kota menggunakan GSV.

- Menggunakan data GSV dengan cara mengakses secara langsung pada laman google.com/maps.

- Memberikan contoh kasus dari dalam dan luar negeri yang membahas mengenai topik tertentu dengan menggunakan data GSV. Contoh kasus dari luar negeri dipilih karena memiliki transformasi perubahan ruang luar yang menarik. Sedangkan contoh kasus dari kota-kota di Indonesia dipilih karena tingginya perubahan fungsi guna lahan yang ada di sepanjang pantai utara pulau Jawa.

- Mengulas setiap data kepustakaan yang diperoleh dengan metode naratif.

- Menganalisis dan mengelompokkan setiap ulasan ke dalam topik bahasan beserta kesimpulan.

Untuk dapat membuka GSV, maka ada tahapan yang harus dilakukan:

- Membuka laman google.com/maps;

- Menuliskan tempat yang ingin diamati;

- Menemukan ikon manusia di sudut kanan bawah dan menariknya menuju pada titik yang ingin diamati, hingga muncul garis-garis biru yang menunjukkan street view. 


\section{Hasil dan Pembahasan}

\section{Streetscape Evaluation}

Evaluasi lanskap tepian jalan (streetscape) dapat dilakukan menggunakan data GSV. Penilaian dilakukan oleh tim ahli maupun responden tertentu yang menjadi sasaran target. Streetscape menunjukkan adanya hubungan antara bangunan dengan ruang di luarnya yang digunakan baik oleh pejalan kaki maupun kendaraan. Contoh penerapan dari evaluasi ini adalah teknik VirtualSTEPS, yakni kepanjangan dari The Virtual Systematic Tool for Evaluating Pedestrian Streetscapes. Alat ini digunakan untuk menilai streetscape pejalan kaki dengan menggunakan data GSV yang menunjukkan fitur lingkungan skala mikro (SteinmetzWood, et.al, 2019 \& Ross et al, 2019). Fitur ini mencakup 39 item yang dikelompokkan ke dalam 6 domain antara lain:

- Infrastruktur pejalan kaki presence of sidewalk, sidewalk continuity, sidewalk buffer, sidewalk quality, pedestrian signal, pedestrian crossing, crosswalk markings, benches, streetlights, curb cuts, curb cut quality, tactile paving);

- Pelambatan lalu lintas jalan (traffic lights, traffic island, stop lines, stops signs, curb extension, speed bump, bollards, number of traffic lanes, number of parking lanes, driveways);

- Karakteristik bangunan (building height, building setback, building design variation);

- Infrastruktur pesepeda (bike lanes, bike buffer, bike facilities);

- Tempat singgah atau transit (presence of transit, type of transit, transit facilities);

- Estetika lingkungan (trees, shades, nature areas, landscaping, landscape maintenance, presence of litter, graffiti, broken/boarded windows, attractive segment)

Penilaian dilakukan secara kuantitatif (memberikan skor: ada tidaknya fitur yang disebutkan, banyaknya jumlah pepohonan dalam penggal jalan, adanya graffiti, dan lainnya) dan kualitatif (menguraikan kondisi fisik dari tangkapan layar GSV). Dengan menggunakan alat observasi ini, pengamatan dapat dilakukan tidak hanya pada penggal jalan yang berbeda, namun juga sangat memungkinkan dilakukan pada tiap kota yang berbeda untuk medapatkan studi komparasi.

Evaluasi lanskap tepian jalan berkaitan dengan pengamatan yang dilakukan dengan menyusuri bagian kota dengan berjalan kaki. Saat menyusuri ruang kota, kita akan menangkap informasi elemen fisik dan memberikan respon terhadap elemen fisik tersebut. Respon inilah yang kemudian diberi nama dengan urban design quality (Ewing \& Clemente, 2013) yang diuraikan ke dalam variabel berikut:

\section{- Imagebility}

Kualitas yang membuat tempat memiliki keunikan, berbeda dengan tempat yang lain, dan berkesan. Sebuah tempat memiliki imageability tinggi saat fitur elemen fisik menarik perhatian pejalan kaki dan meninggalkan kesan yang mendalam. Imageability erat kaitannya dengan "sense of place".

\section{- Transparance}

Variabel ini merujuk pada tingkatan visual di mana seseorang dapat melihat apa yang ada di balik sebuah ruang kota baik itu benda maupun aktivitas manusia. Bentuk dari transparency dapat berupa 
dinding, jendela, pintu, pepohonan, kaca, dan lainnya.

\section{- Enclosure}

Sebuah tingkatan ketertutupan sebuah jalan atau ruang kota yang dibatasi oleh elemen vertikal seperti bangunan, pohon, dinding, dan lainnya. Enclosure juga erat kaitannya dengan skala ruang. Alun-alun kota atau tanah yang lapang memiliki enclosure yang lebih rendah dibandingkan dengan sidewalk di antara bangunanbangunan tinggi.

\section{- Human scale}

Variabel ini merujuk pada ukuran, tekstur, dan artikulasi elemen fisik yang sesuai ukuran dan proporsi dari tubuh manusia dan dapat diamati saat pengamat berjalan kaki. Detail bangunan, tekstur jalan, pepohonan, street furniture merupakan semua elemen fisik yang memberikan kontribusi pada human scale.

\section{- Complexity}

Kekayaan visual dalam suatu tempat yang sangat tergantung pada lingkungan fisik, banyaknya bangunan, ornamentasi arsitektur, penanda, street furniture, dan aktivitas.

Penilaian urban design quality dilakukan secara kuantitatif, yakni dengan memberikan skor pada tiap variabel, dengan pertanyaan seperti: jumlah plaza, jumlah bangunan lama, jumlah lampu, dan lainnya (Clemente et al, 2005). Namun pengukuran urban design quality ini juga menampilkan panel komen dari seorang ahli yang paham mengenai Kawasan tersebut (expert panel).

Observasi kota khususnya untuk mengevaluasi streetscape dapat juga dilakukan dengan menggunakan data GSV untuk teknik serial vision. Serial vision merupakan teknik klasik yang popular dikenalkan oleh Culen (1961) kemudian dikembangkan dan dipraktekkan dengan melakukan segmentasi data pada setiap visionnya (Kalin \& Yilmaz, 2012; Nugroho et al, 2013; Nugroho, 2015). Segmentasi data dilakukan untuk menyederhanakan gambar sehingga diketahui tingkat visibilitas dari tiap properti (bangunan, jalan, vegetasi, langit) seperti yang ditunjukkan Gambar 1. Teknik serial vision dengan cara mengambil gambar atau foto secara langsung di lapangan ini, dapat dilakukan dengan menggunakan data GSV mengingat bahwa data yang ada pada GSV juga menerapkan pandangan secara berseri (serial vision).

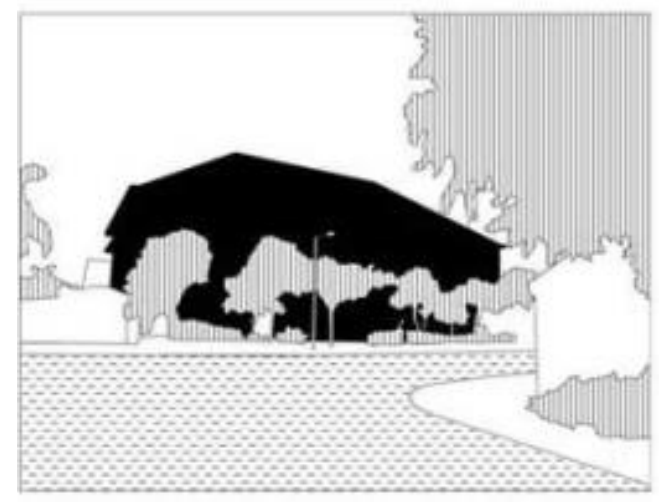

Gambar 1. Segmentasi pada serial vision Sumber: Nugroho, 2015

Urban Transformation of Public Space

GSV mulai diluncurkan pada tahun 2007. Sehingga pada beberapa Kawasan perkotaan, memiliki rekaman data yang cukup bervariasi. Dalam perbedaan waktu yang lama ini, bagian dari kota telah berkembang karena kebutuhan masyarakatnya. Misal sebuah lahan yang awalnya kosong berubah menjadi supermarket, komplek hunian, atau lainnya. Gambar 2 menunjukkan adanya transformasi 
ruang publik yang terekam oleh GSV dalam rentang waktu 7 tahun. Dua perbandingan gambar ini menunjukkan perubahan antara lain: perubahan material permukaan jalan, penutupan sebagian jalan untuk pejalan kaki dilengkapi dengan tanaman, curb design, penyediaan jalur sepeda, pelebaran ruang pejalan kaki pada jalan utama.

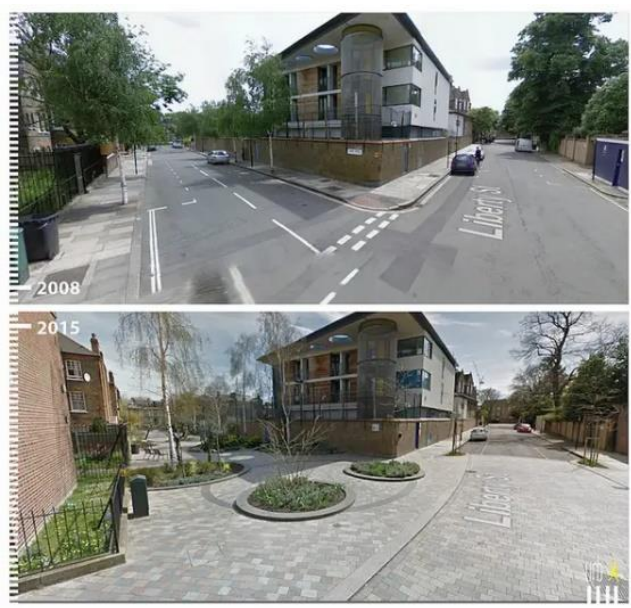

Gambar 2. Van Gogh Walk, London, England Sumber:

https://www.businessinsider.com/googlestreet-view-public-space-transformations2017-6, diakses 19 Maret 2021

Urban transformation pada ruang luar di atas erat kaitannya dengan perbaikan dan peningkatan walkability dalam satu penggal jalan. Perhatian yang besar pada pejalan kaki dengan memperhatikan kenyamanan psikologi seperti: kebutuhan akan ruang sosial (bangku, street dining area, street café), tanaman (semak, perdu, dan pohon) dan elemen perabot jalan seperti penyediaan bollards, street lighting, dan lainnya. Contoh pada Gambar 2 menunjukkan perbedaan yang mendasar yaitu car-oriented urban design dan walking-oriented urban design. Perubahan ruang publik kota dari car-oriented urban design menjadi walking-oriented urban design sangat berhubungan erat dengan perencanaan transportasi kota secara menyeluruh. Penutupan jalan yang tidak bisa dilalui kendaraan bermotor harus dibarengi dengan penyediaan sarana dan prasarana transportasi publik yang memadai.

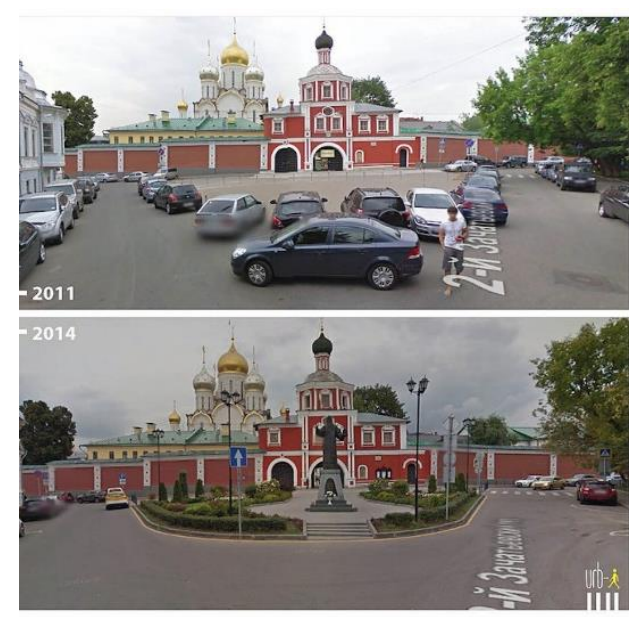

Gambar 3. Moscow Zachatyevskiy per., Moscow, Russia Sumber:

https://www.businessinsider.com/googlestreet-view-public-space-transformations2017-6, diakses 19 Maret 2021

Penerapan lain pada observasi melalui GSV adalah perbaikan lingkungan di Moscow Zachatyevskiy per., Moscow, Russia pada Gambar 3. Pada GSV tahun 2011, bangunan memiliki ruang luar dengan tiang-tiang bollard sebagai penanda batas antara parkir mobil dan area bagian bangunan. Ruang luar sebagai ruang transisi ini kemudian diubah seperti yang terlihat pada GSV tahun 2014. Orientasi, area masuk ditekankan melalui statue yang diletakkan di depan bangunan, satu sumbu lurus dengan pintu masuk utama. Tanaman perdu menggantikan tiang bollard sebagai pembatas ruang. Di sini, tanaman tidak hanya menjadi batas visual namun juga berperan sebagai visual comfort dalam ilmu townscape. 
Dalam menikmati ruang publik, manusia membutuhkan elemen-elemen street furniture yang dapat memberikan perasaan tenang dan menyenangkan. Elemen air, merupakan salah satu cara memberikan efek psikologis yang tenang dalam lingkungan perkotaan yang kental dengan suasana hiruk-pikuk. Perluasan kolam sekaligus pembebasan area dari kendaraan bermotor diharapkan menciptakan sense of safety dan sense of comfort untuk menikmati ruang publik kota seperti yang ditunjukkan pada Gambar 4.

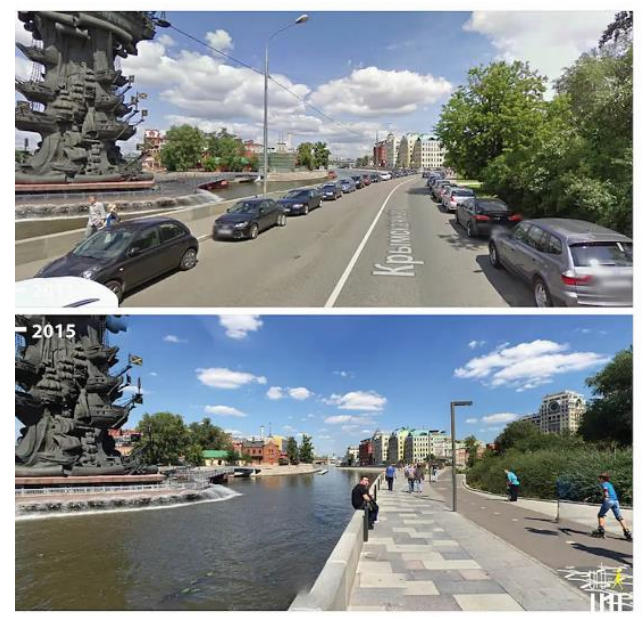

Gambar 4. Perubahan ruang luar publik di Moscow Rusia Sumber:

https://www.businessinsider.com/googlestreet-view-public-space-transformations2017-6, diakses 19 Maret 2021

Dalam mengamati

urban transformation pada data GSV, maka variabel-variabel yang diamati sebaiknya adalah yang mudah dilihat secara langsung pada GSV. Setidaknya ada dua hal yang dapat diamati pada data GSV, yakni: architectural characteristics dan streetscape design. Analisis yang dapat dilakukan adalah menjelaskan tiap variabel, membandingkan dua periode yang berbeda, dan melakukan penilaian secara deskriptif kualitatif. Walau demikian, analisis yang dilakukan bisa lebih dari deskriptif kualitatif. Data pada GSV merupakan big data yang juga dapat dikuantifikasi menggunakan mathematic modelling. Selain dari itu, sudut pandang dari transportation planning, route choice, travel behaviour juga dapat memperkaya hasil analisis yang akan disusun.

\section{Tracking the History}

Tracking the history berkaitan dengan urban transformation namun lebih menekankan pada penelusuran sejarah arsitektur melalui bangunan lama yang ada di dalam sebuah kota. Berkembangnya kota kadang memaksa bangunan lama untuk berubah menjadi bangunan baru yang dinilai lebih dapat memberikan keuntungan secara ekonomi. Bangunan-bangunan lama yang berada pada pusat kota memiliki potensi untuk berubah, baik itu berubah menjadi lebih baik (adaptivereuse) maupun berubah menjadi bangunan lain.

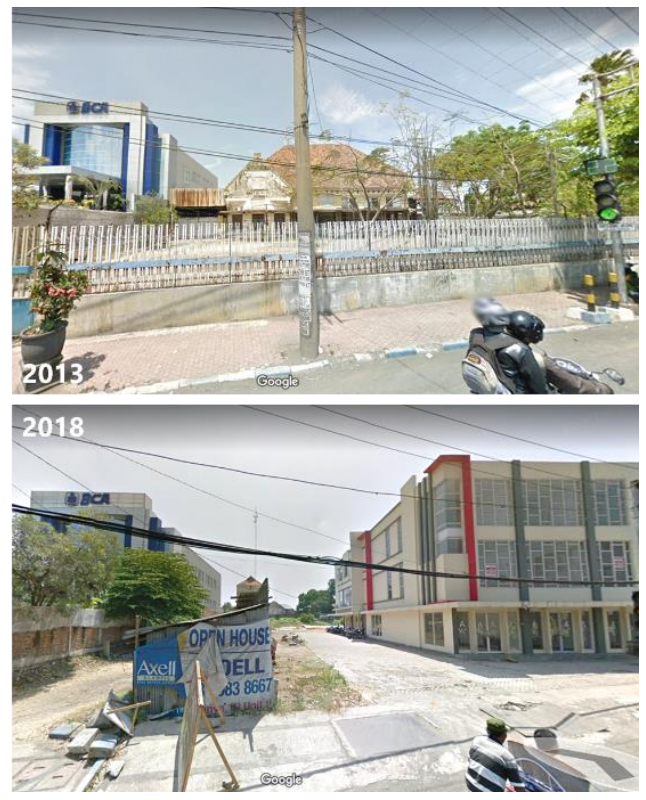

Gambar 5. Bangunan lama di jalan protocol kota Pasuruan Sumber:

https://goo.gl/maps/fceukLi19iC4fw7FA diakses 3 Mei 2021 
Obyek yang sering berubah adalah bangunan yang berada di jalan arteri primer. Di pulau Jawa, salah satu contoh jalan utama yang menghubungkan kota-kota di pesisir utara pulau Jawa adalah jalan Pantura (Pantai Utara). Gambar 5 menunjukkan sebuah bangunan di jalan protokol kota Pasuruan yang berubah menjadi kompleks pertokoan. Di jalan ini banyak berdiri bangunan-bangunan besar bergaya arsitektur Tionghoa dengan campuran arsitektur Eropa yang menunjukkan kemakmurannya di abad 19, seperti pada Gambar 6 (Handinoto, 1990).

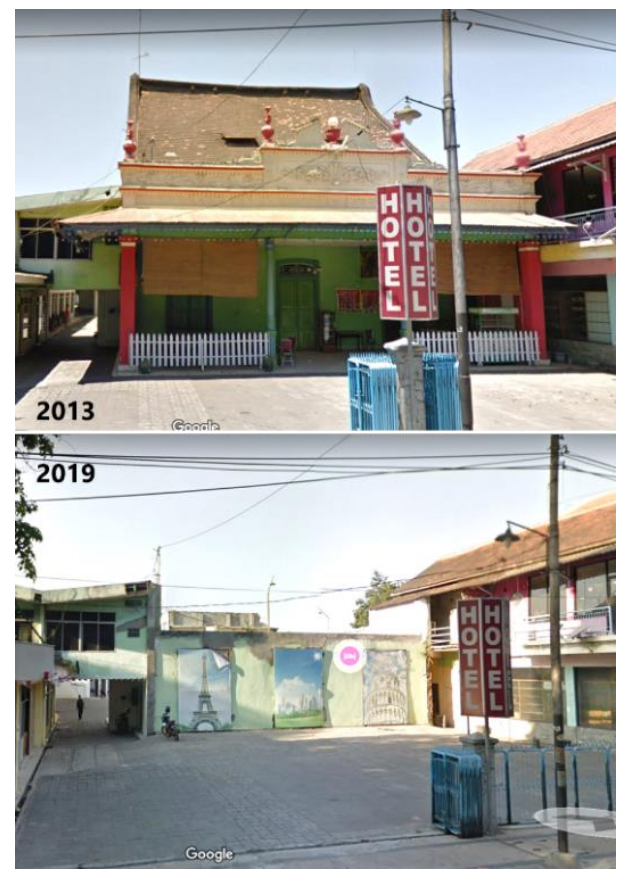

Gambar 6. Bangunan lama di kota Pasuruan yang perlahan hilang Sumber:

https://goo.gl/maps/1RioTR2B8GJoS4CX6, diakses 3 Mei 2021

Rumah pada Gambar 6. Menunjukkan bangunan inti dengan dua sayap kiri dan kanan sebagai paviliun. Rumah dengan paviliun terpisah merupakan tipikal bangunan lama khususnya yang memiliki luas tanah yang besar. Pada rumah inti, terdapat teras yang luas dengan tiga pintu. Walaupun bangunan yang terekam pada data GSV di tahun 2013 tidak sepenuhnya asli, namun bentuk atap dan gewel depan menjadikan tolok ukur perwujudan dari bangunan lama. Perubahan juga terjadi pada Gambar 7, namun bangunan lama tidak seluruhnya dihancurkan seperti Gambar 6. Bangunan atau rumah mencerminkan identitas dari penghuninya. Adanya keinginan penghuni untuk mengubah bagian dari bangunan menyebabkan berubahnya wujud bangunan secara keseluruhan. Misalnya, rumah lama yang awalnya memiliki teras luas kemudian berubah menjadi ruang tertutup yang masif, selasar yang berubah menjadi kamar maupun gudang, dan lainya. Gambar 7 menunjukkan perubahan rumah dari yang semula kental dengan arsitektur Tionghoa, menjadi bangunan dengan pengaruh arsitektur Jengki (data GSV tahun 2013), hingga menjadi bangunan dengan tampilan yang lebih sederhana dengan menghilangkan kekhasan atapnya (data GSV tahun 2019).

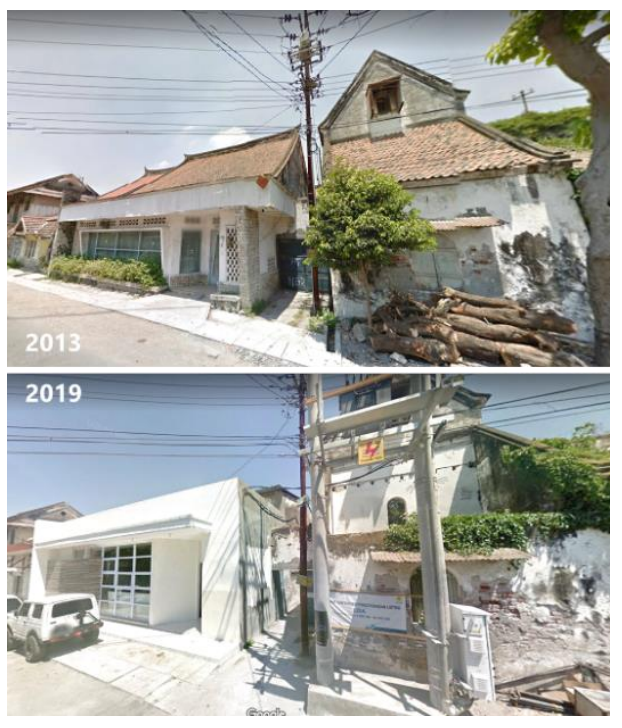

Gambar 7. Merekam jejak sejarah arsitektur di Gresik Sumber:

https:/goo.gl/maps/tkT9wom9kwBeKk736, diakses 3 Mei 2021 
Observasi karakter fisik arsitektur dapat juga dilakukan melalui sketsa ulang dari data GSV seperti yang ditunjukkan oleh Gambar 8. Dengan melakukan sketsa ulang, maka secara tidak langsung akan mengamati secara detail tiap bagian dari elemen bangunan: atap, badan, dan ornamentasi (bagaimana bentuk atapnya, bagaimana bentuk gewelnya, apakah ada ornamentasi khusus di bagian atap, apakah memiliki balkon dan bagaimana wujudnya, bagaimana bentuk teritisan atap, bagaimana bentuk handrail pada balkon dan teras, dsb). Bangunan lama yang ada di jalan Nias, kota Surabaya (Gambar 8) merupakan bangunan dengan wujud yang tidak dimiliki oleh bangunan lain. Namun, keunikan ini hilang seiring dihancurkannya bangunan ini pada data GSV tahun 2018. Sketsa membantu mengurai Kembali detaildetail unik yang ada dalam tipologi bangunan lama di kota Surabaya. Dengan kata lain, sketsa ulang pada data GSV dapat melatih kepekaan dalam melihat karakter fisik arsitektur.

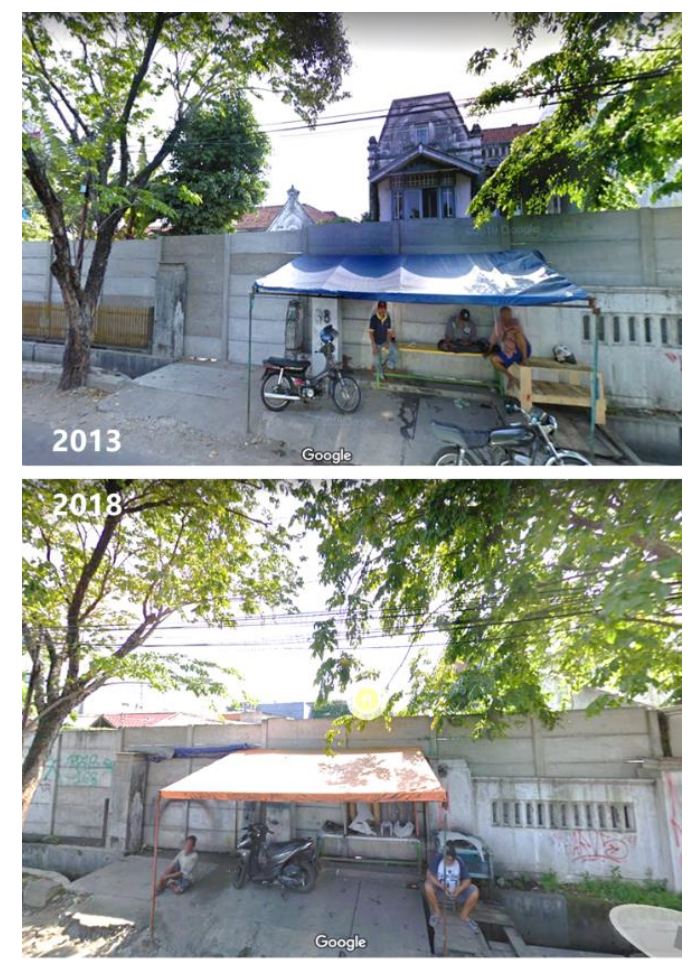

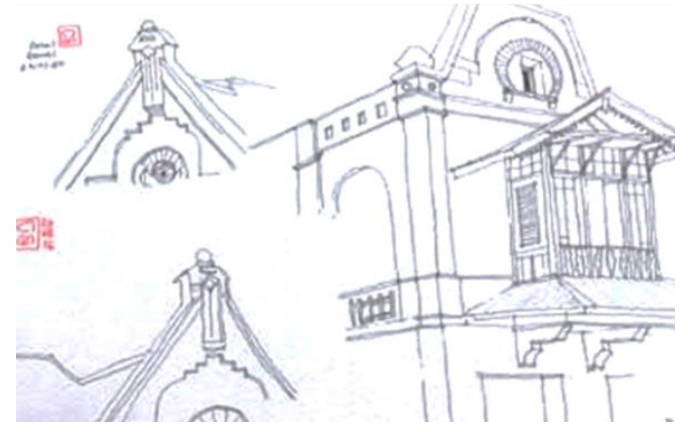

Gambar 8. Elemen arsitektur bangunan yang pernah ada di Jalan Nias Surabaya Sumber:

https://goo.gl/maps/pgzF4NyU7NZfNZaj7 diakses 3 Mei 2021 dan sketsa dokumentasi Nugroho, 2015

Dari hasil dan pembahasan di atas, diperoleh kelebihan dan kekurangan dalam menggunakan data GSV untuk observasi kota. Kelebihan dari observasi ini antara lain adalah: pertama, fleksibilitas. Observasi dapat dilakukan dari mana saja, dan obyek dapat diamati dapat beragam. Sehingga studi komparasi antar beberapa kawasan dalam satu kota, antar kota dalam satu negara, maupun antar kota dalam negara yang berbeda, sangat mungkin untuk dilakukan. Kedua, big data. Data yang disajikan oleh GSV merupakan big data yang mencakup banyak informasi di dalamnya. Tergantung dari data apa yang digunakan dan teknik analisis apa yang akan digunakan. Meskipun demikian, observasi ini juga tidak menutup kemungkinan banyaknya kekurangan, terutama adalah observasi secara tidak langsung tidak akan mampu menggantikan observasi langsung yang melibatkan seluruh inderawi khususnya peraba, penciuman, perasa, dan pendengaran. Berbeda dengan observasi yang dilakukan secara langsung, interview secara langsung dengan warga atau masyarakat sekitar sangat mungkin dilakukan untuk memperdalam data yang ingin dikumpulkan. Sedangkan, pada 
observasi ini, pengumpulan data opini dari masyarakat tidak dapat dilakukan secara bersamaan. Data interview dengan responden dapat dilakukan terpisah secara langsung (offline atau tatap muka) maupun tidak langsung (online questionnaire).

\section{Kesimpulan}

Pemanfaatan data GSV untuk kebutuhan observasi menjadi peluang yang paling memungkinkan untuk dilakukan di tengah pandemi covid-19. Artikel ini membahas sebagian kecil penerapan observasi menggunakan data GSV yang setiap penerapannya memiliki topik yang berbeda, namun tetap berada dalam bidang arsitektur dan perancangan kota. Menjawab rumusan permasalahan pada artikel ini, maka topik yang dapat diulas dengan menggunakan data GSV antara lain: Pertama, penilaian lanskap jalan dan infrastruktur. Dapat menggunakan Virtual-STEPS, Urban Design Quality, GSV Segmented Serial Vision, dan Urban Transformation of Public Space. Kedua, pelestarian arsitektur dan kota dengan menggunakan Urban Design Quality, Urban Transformation of public space, dan Tracking the history. Ketiga, pembacaan karakter arsitektur dan Kawasan sekitar, dengan menggunakan Urban Design Quality, dan Tracking the history.

Dalam pembahasan artikel ini, penulis memahami bahwa masih ada banyak contoh penerapan yang memanfaatkan data GSV khususnya yang fokus pada sisi teknik permodelan dengan pendekatan kuantitatif. Penulis berharap bahwa artikel ini dapat memberikan referensi secara ilmiah mengenai observasi data arsitektur dan kota di tengah pandemi khususnya di dunia proyek penelitian dan pengajaran bidang arsitektur dan perancangan kota.

\section{Daftar Pustaka}

Anguelov, D., Dulong, C., Filip, D., Frueh, C., Lafon, S., Lyon, R., Ogale, A., Vincent, L., Weaver, J. (2010). Google Street View: capturing the world at street level, Computer, 43, 32-38.

APJII. (2020). Laporan survei internet APJII 2019 - 2020 (Q2). Asosiasi Penyelenggara Jasa Internet Indonesia.

Clemente, O., Ewing, R., Handy, S., Brownson, R., \& Winston, E. (2005). Measuring urban design qualities - an illustrated field manual. Princeton, NJ: Robert Wood Johnson Foundation.

Cullen, G. (1961). Townscape. New York: The Architectural Press.

Ewing, R. \& Clemente, O. (2013). Measuring urban design: metrics for livable places. Washington: Island Press.

Gehl, J. \& Svarre, B. (2013). How to study public life. Washington: Island Press.

Gebru, T., Krause, J., Wang, Y., Chen, D., Deng, J., Aiden, E. L., Fei-Fei, L. (2017). Using deep learning and google street view to estimate the demographic makeup of neighborhoods across the United States. Proceeding of the National Academy of Sciences of the Unites States of America (PNAS) 114 (50) 13108-13113.

Handinoto. (1990). Sekilas tentang Arsitektur Cina pada akhir abad ke 19 di Pasuruan. Dimensi, 15,1-18.

Kalin, A., Yilmaz, D. (2012). A study on visibility analysis of urban landmarks: the case of Hagia Sophia (Ayasofia) in Trabzon. Journal of the Faculty Architecture. 
Middle East Technical University, 29, 241-271.

Lipovská, B., Štěpánková, R. (2013). Assessing observation methods for landscape planning practice in rural villages. Current Urban Studies, 01, 102-109.

Mungkasa, O. (2020). Bekerja dari rumah (working from home/wfh): menuju tatanan baru era pandemi covid 19. The Indonesian Journal of Development Planning, 4, 126-150.

Nugroho, S. (2015). Peningkatan visibilitas bangunan lama, studi kasus jalan krembangan barat Surabaya. ATRIUM: Jurnal Arsitektur. 01, 167-179.

Nugroho, S., Darjosanjoto, E. T. S. (2013). Study of sequential views in krembangan district to improve visual quality. Proceeding of $7^{\text {th }}$ International Conference on Planning and Design (ICPD) in National Cheng Kung University, Tainan, Taiwan, 491-500.

Ross, N., Steinmetz-Wood, M., Velauthapillai, K., O'Brien, G. (2019). Virtual systematic tool for evaluating pedestrian streetscapes (virtual-steps) background and auditing methodology guide. Montreal: Geo-Social Determinants of Health Research Group Department of Geography, McGill University.

Rzotkiewicza, A., Pearsona, A. L., Doughertya, B. V., Shortridgea, A., Wilson, N. (2018). Systematic review of the use of Google Street View in health research: major themes, strengths, weaknesses and possibilities for future research. Health \& Place, 52, 240-246.

Sainju, A. M., Jiang, Z. (2020). Mapping road safety features from streetview imagery: a deep learning approach. ACM/IMS Transactions on Data Science, No.: 15, 1-20.
Soemardiono, B., Rachmawati, M., Ardianta, D. A., Nugroho, S. (2019). Spatial analysis of urban dense area in developing criteria design based on people participation: case study of Kembang Jepun, Surabaya. Geographia Technica, 14, 13-21.

Steinmetz-Wood, M., Velauthapillai, K., O’Brien, G., Ross, N. (2019). Assessing the micro-scale environment using Google Street View: the Virtual Systematic Tool for Evaluating Pedestrian Streetscapes (Virtual-STEPS). BMC Public Health. 19, 1246 (2019).

Vandeviver, C. (2014). Applying Google Maps and Google Street View in criminological research. Crime Science 3, 13 (2014).

Zed, M. (2014). Metode penelitian kepustakaan. Jakarta: Yayasan Obor Indonesia. 